\title{
Public Expenditure on Education; A Measure for Promoting Economic Development
}

\author{
Syed Shabib ul Hasan ${ }^{1}$, Syeda Umaima Riaz ${ }^{2}$ \\ ${ }^{I}$ (Assistant Professor, Department of Public Administration, University of Karachi, Karachi - 75270, Pakistan) \\ ${ }^{2}$ (Research Student; Department of Public Administration, University of Karachi, Karachi - 75270, Pakistan)
}

\begin{abstract}
The rational utilization and allocation of public expenditure would result into an economic development of the country. It has been observed that allocation and utilization of expenditure in Pakistan have been very little towards development. The allocation of current expenditure such as debt servicing and defense has increased by a greater percentage every year as compared to education. Money borrowed by the economy over the years, if had been put to the development of projects, the economy would have seen much higher development and growth. The objective of the research lies in evaluating the public expenditure and its role in economic development by considering education as an indicator to social development in Pakistan.
\end{abstract}

Key Words: Public Expenditure, Economic Development, Education.

\section{Introduction}

Development is a phenomenon which has divided countries in different sets, thus those who are developed are working on its sustainability and countries that are less developed eager to attain economic development. In Pakistan's case, the economy could be categorized as developing country based on the resources it owns and the potential it has. However the economic policy makers have not shown consistency in their objectives and actions resultantly the economy is reeling on the edge of being declared as economically failed state. Pakistan is striving and functioning towards the attainment of developed economy status by pursuing development by way of incurring huge expenditures in various sectors of the economy. (Dewett \& Chand, 1987, p. 546)

"Public expenditure refers to the expenses which the government incurs for its own maintenance and also for the society and the economy as well." (Bhatia, 1996, p.231) Although, Government of Pakistan has managed to spend millions of dollars in elevating the economic growth and development but it has proved to be inefficient and unproductive. As a matter of fact, Pakistan has been facing the problem of instable economy for many years, however according to economic survey (2010-11) issued by the Ministry of Finance, "the economy has considerably lost significant growth momentum during last three years averaged just $2.6 \%$ as against $5.6 \%$ in the preceding eight years. "The economic growth of the country is the key to progress "from the state of under development to a state of development, from an agrarian to a highly industrialized society, from a low saver to high saver and from a predominantly rural to predominantly urban society.” (Dewett \& Chand, 1987, p. 640)

The neighboring economies of the region such as India, Bangladesh had also started process of development in the same circumstances since their independence, but there has been a significant growth and development there compared to what could be observed in Pakistan. Understanding the importance of public expenditure, Pakistan has been increasing the funds for it every year despite the fact that transformation of that expenditure into development is moving up the ladder at snail's pace. Many countries gave a boost to their economies by promoting development expenditure.

\section{Determinants of Economic Development}

Economic development in actual is closely linked with continuous and sustainable economic growth. World Bank has defined economic development as the "qualitative change and restructuring in a country's economy in connection with technological and social progress. The main indicator of economic development is increasing GNP per capita (or GDP per capita), reflected through an increase in the economic productivity and general material well being of a country's population." "Public expenditure refers to the expenses which the government incurs for its own maintenance and also for the society and the economy as well." (Bhatia, 1996, p.231)

The possible goals of economic development are the availability of basic needs to the people of the country, well being of the citizens through high levels of income, literacy and more consumption of goods and services than before. In its essence it is aimed towards "expanding the range of economic and social choices available to individuals." (Todaro, 2000, p. 18) The level and intensity of the economic development are usually gauge by factors that determined whether the country is moving in the right direction or not. These factors are 
typically classified into two broad categories; economic factors and non-economic factors. The former are further divided into availability of resources, capital formation, technology, human resources, entrepreneurship and growth of population. Non-economic factors are political, social and administrative factors. (Dewett, 1987; Herrick \& Kindleberger 1983)

Availability of resources means land and other natural resources such as water, forests, and minerals etc. These resources are the chief ingredient in the development process as countries that are rich in natural resources usually maximizes its effective utilization for rapid and sustainable development. Through persistent policies higher level of development is not difficult to attain, however if such a commitment is nonexistent economies would find themselves failed in the proper utilizing their resources. Such a situation makes their economic activities to slow down and hamper the growth process. Lack of growth has its repercussions in the form of lack of capital formation which is an important element for capital accumulation thereby economic prosperity suffers. According to Dewett \& Chand (1987, p.642) "capital formation is the very core of economic development" and by planting factories, building infrastructure and industries it can be achieved.

Capital formation and capital accumulation further helps in technological advancement of an economy. It has been observed that those economies which have found wealth being accumulated in the previous time period usually finds it easier to sponsor research and development activities and made further economic advancements. Economic progress in LDCs is significant for their economic stability, growth and development, which could not be achieved without advancement in modern technology. However developing countries usually find it difficult to raise the level of economic growth due to the fact that most of the developing countries either lack in resources or have political instability. The situation contributes towards lack of opportunities to have technically advance environment owing to less capital formation. "Technical efficiency is producing more with the same inputs or producing the same quantity of output with fewer inputs." (Herrick \& Kindleberger, 1983, P.222) Most of the LDCs including Pakistan are taking initiatives to improve their level of technology but still a long way is ahead to reached development.

Human resources are the key resources of any country; the skilled, literate and healthy people can be productive to promote economic development. They are as important as capital and other resources without the effective and indigenous people the efficient utilization of the other resources are not possible. Any economy could consider itself lucky if it has more population of young and energetic people who can easily make the process of development move faster. However, if the economy either has lesser supply of such people or have not done enough to tone them towards contributing efficiently for the economy, it would be difficult to move the wheel of economic development move in the right direction. One such area could be to encourage and support the youth towards embarking on entrepreneurial projects and carry the economy forward. The existence of energetic private sector is important for economic growth as they bring together all factors of production which generate economic activities. Growth of the population also affects economic development if the population growth is higher it will affect the economic progress and will lead to other economic problems such as food problem and unemployment, yet if it is too small it will not generate economic activities sufficient to economic growth.

Economic stability is strongly linked to socio-political stability; political factor has a great influence on the economy of the countries. Their efficient policies and reforms can bring a change in the fields of education, industries, transport and other economic and social overheads. Economies having political problems find it hard to identify their goals and targets effectively and ultimately keep on chopping and changing their course of action which leads them nowhere. Whereas economies having defined objectives and national consensus on such targets makes it easier to pursue it through policy analysis and policy advocacy. Political instability has a negative consequence in the form of non existent systems as such instability usually does not allow institution to build. Political stability is also significantly linked norms of the society. Social factors involve attitudes, customs and culture of a particular country. In developing economies this is one of the dominant factors that influences economic development as such economies carries a social culture of spending money extensively on festivals, marriages and religious activities which affect their level of savings.

Public expenditure has a significant role in positively affecting all the above defined economic determinants of economic development. Public expenditure if used in the development programs would open the way for growth and expansion in developing economies. The private sector has the willingness towards allocating resources for maximizing their profit while the public sector, in its quest of welfare for all, would be interested in uplifting the social standard of the economy. Public sector could achieve this by spending in the right activities like education, developing resources and enhancing the infrastructure facilities. Furthermore public investment in the remote or backward regions can lessen the regional disparity and controls the influx of people towards urban center thereby securing itself form further socio-economic crises.

In addition, public expenditure in research and development activities can lead to the innovation in production technologies, dearly needed by the developing economies. Such countries are still compelled to use outdated means of production that is inefficient for adequate production both in agriculture and industrial sector. 
Proper public expenditures in different sectors of the economy can propel the economy in the right direction and helps people raise their standard of living.

\section{Economy Of Pakistan}

Pakistan is developing country with the population of 180 million; Pakistan has been driving itself hard towards development and putting all efforts to raise the level of economic growth. The economists have divided the Pakistan economy into three eras; 1947-1970, 1971- 1990 and 1991-2010. Establishing an economic structure after independence was very difficult as Pakistan was lacking many of essential resources however after struggling Pakistan has maintained its economic stability. Pakistan's average economic growth rate in the first 50 years has been higher than the average growth rate of the world economy during the period which was $6.8 \%$ in the $1960 \mathrm{~s}, 4.8 \%$ in the $1970 \mathrm{~s}$, and $6.5 \%$ in the $1980 \mathrm{~s}$ respectively. The level of growth and development has also increased in the mid 60s. In 1980s the growth was highest in comparison to regions like Bangladesh, Sri Lanka and India. "In 1990s Pakistan encountered a deep and protracted recession, since GDP growth declined from 6.1 percent during 1980s to 4.2 percent during 1990s."(Baluch \& Razi, 2007, p.57)

Due to government spending on development projects the period of 2001-2007 has lessened the poverty to $10 \%$ and growth were $5-8 \%$ in range till 2004-2007. In 2008 there was a drastic decline in growth i.e. $1.7 \%$. Currently the growth has lost the momentum and decline to $2.4 \%$. Pakistan has been facing the challenges of poor education, health, and power problem which can be tackled through expanding government investment in these areas.

\section{Public Expenditure in Pakistan}

Government expenditure is divided into current or non developmental expenditure and development expenditure. Non developmental expenditure is used for "maintenance of internal security, law and order etc."(Dewett \& Chand, 1987, p.542) Development expenditure refers to starting new projects in those sectors that encourage and promote economic development. In Pakistan current expenditure spend on "debt servicing and repayment, defense, administration, social and economic services, law and order, railway and others." (Federal Budget 2011-12) The borrowing from external and internal sources has become a burden to Pakistan as the principal amount with interest has to be paid. The debt burden of Pakistan has reached to $\$ 130$ billion. Budget allocations for defense expenditures reflect rising trend whereas the grants to Azad Jammu Kashmir are also part of the government expenditure. Subsidies on edible consumer products also provided to lessen the burden on consumers, however all these expenditure leaves lesser amount of money left for the developmental expenditures.

Development expenditure of Pakistan is comprised of all the economic and social sectors of the country including agriculture, transport and communication, health, education, industries, water, power, fuel and minerals, woman welfare, manpower and employment, northern areas of country, AJK, FATA etc. The expenditure is allocated under the name of Public Sector Development Program (PSDP) which is further divided into Integrated Social Public Works Program (ISPWP) and Khushhal Pakistan (Prosper Pakistan). The development expenditure should be incorporated with the aim of improving country's physical resources, knowledge and skills of people and efficient use of available resources. Pakistan has been incurring money every year on both current and development expenditure, however by having fair means of utilization and allocation of resources it can lead to economic development.

\section{Public Expenditure Analysis of Pakistan:}

This study has focused the comparative approach to assess the public expenditure of Pakistan with the help of statistics and analyzed that how much government contributed to the development in past 10 years. It has been identified through literature human resources are the key factor in the process of economic development, so the study has examined and compared the education sector of Pakistan with different countries of the region. The statistics below clearly identified the areas of public spending in Pakistan; the development expenditure was very low in comparison to current expenditure during 2001-2004. Nonetheless it has increased by $4 \%$ in 2005 and $6 \%$ in 2006 respectively, due to the fact that the economy was having no issue of liquidity. But afterwards there was a continuous decline from thereon as the economic activity has been marred by variety of political and social issues. Although, public expenditure is growing every year but development expenditure curtailed in proportion to current expenditure as in 2010 development expenditure was $10.3 \%$ only of total expenditure. 
Public expenditure on education; a measure for promoting economic development

Table: 1 Total Public Expenditure Incurred in Pakistan over a Decade.

\begin{tabular}{l|c|c|c|c|c}
\hline Years & $\begin{array}{c}\text { Current Exp. } \\
\text { as \% TE }\end{array}$ & $\begin{array}{c}\text { Dev. Exp. } \\
\text { as \% TE }\end{array}$ & Defence as \% TE & $\begin{array}{c}\text { Subsidies \& } \\
\text { Grants as \% TE }\end{array}$ & $\begin{array}{c}\text { Debt Servicing as } \\
\% \text { TE }\end{array}$ \\
\hline $2001-02$ & 84.7 & 15.3 & 18.1 & 3.5 & 52.5 \\
\hline $2002-03$ & 88.1 & 14.4 & 17.8 & 6.4 & 31.6 \\
\hline $2003-04$ & 81.1 & 16.8 & 19.3 & 7.1 & 36.6 \\
\hline $2004-05$ & 77.4 & 20.4 & 19.0 & 6.0 & 26.2 \\
\hline $2005-06$ & 73.8 & 26.0 & 17.2 & 7.2 & 24.4 \\
\hline $2006-07$ & 76.4 & 24.1 & 13.9 & 4.2 & 25.4 \\
\hline $2007-08$ & 81.4 & 19.9 & 12.2 & 18.6 & 25.4 \\
\hline $2008-09$ & 80.7 & 19.0 & $20.5^{*}$ & $14.6^{*}$ & 34.8 \\
\hline $2009-10$ B & 78.6 & 21.1 & $17.2^{*}$ & $11.8^{*}$ & 27.1 \\
\hline
\end{tabular}

Source: Sherani, S. \& Gul, N. "Public Finance” Economic survey of Pakistan (2009-2010)

The major share of the expenditure has been incurred on debt servicing and defense, although spending on defense is crucial as the economy is experiencing and endangered by the threats from both within and across the border. However from economic development perspective, spending money on defense at the cost of other development projects has proved to be detrimental for the economy. Furthermore, in order to maintain security measures Pakistan has to borrow money which has increased debt servicing and huge amount with interest has to be paid to the lender, which in turns again cut from the development expenditure that further affects the process of economic development. According to Stockholm International Peace Research Institute, Pakistan military expenditure was Rs. 49.2 billion in 1988 which has exceeded to 568 billion in 2011 and ranked 33 among 153 countries in military expenditure (2.8\% of GDP). "An examination of a budgetary trade-off found that economic services as a whole were adversely affected by military expenditures.” (Abbas \& Mushtaq, 2006)

\section{Public Expenditure in Education}

Worst affected area of the economy due to these huge allocations for defense and debt servicing is education which is the most significant factor in encouraging the economic development. Developed economies have attained economic development only by investing in right proportion to the education of its people and it has been justified by the standing they have among nations of the world. It could be argued by that the level the developed countries have attained was not because of focusing on physical capital but it was the human factor that helped them in their progress. (Todaro, 2000, p.343) Even though in developing countries, education has been gaining more and more focus but unfortunately in Pakistan the education has not been able to attract attention of the policy makers as compared to the economies of the region.

Table 2 Literacy Rates among different countries during 2008 and 2011.

\begin{tabular}{|l|l|l|}
\hline Country & Adult Literacy Rate & Youth Literacy Rate \\
\hline China & $94 \%$ & $99 \%$ \\
\hline Sri Lanka & $91 \%$ & $98 \%$ \\
\hline Indonesia & $92 \%$ & $99 \%$ \\
\hline India & $74 \%$ & $82 \%$ \\
\hline Nepal & $59 \%$ & $82 \%$ \\
\hline Pakistan & $58 \%$ & $84 \%$ \\
\hline Bangladesh & $56 \%$ & $75 \%$ \\
\hline
\end{tabular}

Source: http://data.worldbank.org/indicator/SE.ADT.1524.LT.ZS

As the figures above showing that Pakistan and Bangladesh were the lowest in adult literacy rates among all the countries in the region yet youth literacy rate are quite appreciable. However the definition of literacy in Pakistan is taken as someone who can read and write his name only. 
Table 3 Public Expenditure on Education (\% of GDP)

\begin{tabular}{|c|c|}
\hline Country & Public Expenditure on Education as \% of GDP (2009-10) \\
\hline Pakistan & $2.05 \%$ \\
\hline India & $3.3 \%$ \\
\hline Bangladesh & $2.6 \%$ \\
\hline Nepal & $3.3 \%$ \\
\hline Iran & $5.2 \%$ \\
\hline Maldives & $8.3 \%$ \\
\hline
\end{tabular}

Source: Farooq, O. “Education”, Economic survey of Pakistan 2009-10

Similarly the expenditure incurred on education in different regions is higher than those incurred in Pakistan. In the above table Maldives has shown to spend highest percentage of its GDP on education. Malaysia has been able to attract huge foreign investment during the last decade and has attained significant social and economic development mainly by spending almost $28 \%$ of its total public expenditure on education. On the other hand Pakistan is among economies that has spent lowest percentage of their GDP on education and has not increased more than $12 \%$. This could be taken as the reason that Malaysia has been able to build up its foreign reserves by approximately 08 times more than that of Pakistan. This indicates that if Pakistan has to progress than it has to follow the success story of Malaysia that no economy can prosper without spending on education of its people. Pakistan up till now has not been able to divert enough of its resources towards education and one of the indicators could be the school going girls. In Pakistan forty five percent of the girls go to primary level school which is much less in comparison to Bangladesh where the percentage of school going girls at primary level is seventy three percent. Even though Bangladesh is also not spending enough on education out of its GDP but is comparatively much attaining higher economic progress which is $6.3 \%$ compared to $2.4 \%$ only by Pakistan.

To make the matter worse the trend of public spending on education instead of having an upward movement is in fact having a declining tendency. Over a period of last five year, there is a continuous decline in the public expenditure on education in Pakistan (as \% of GDP); it was 2.5\% in 2006-07, 2.47\% in 2007-2008, $2.10 \%$ in $2008-09$ and $2.05 \%$ in 2009-10. Such a low public expenditure could not bring betterment in the lives of the people and is truly reflected through the HDI (Human Development Index). Pakistan is ranked $145^{\text {th }}$ in 2011 which was 0.504 in a group of 187 countries. HDI defines the well being of people in areas of education, health and income.

Although various governments in Pakistan have spend money on education reflected through the numbers of schools, colleges and universities that have been developed in past 64 years. There was around $24 \%$ increased shown in the numbers of education institutes between 1995-2010 reached to approximately 229,000 institutes working with around 1,444,120 teachers and 3,911,100 students. These numbers may give a very resounding and healthy picture, but in terms of the quality much is desired to be done. The literacy rate in rural areas and among female is still very poor and Pakistan can be easily be ranked in top shelves amongst the economies having highest dropout of children from the school.

The higher education specifically universities had seen more growth and encouragement as compared to primary and secondary education. Since 2001 Higher Education Commission (HEC) was allowed to play in uplifting the status of higher education, which has a crucial role in the socioeconomic development. "The type of socio economic development in a country goes hand in hand with the type of its education and the education system." (Aftab \& Ahson; 2009, p.69) It is like a system which transforms the government's input i.e. funds into the skilled and educated workers. Higher enrollments, accessibility to quality, unbiased attitude towards genders and localities and well settled education system could help in the development of the country. Government provided funding to HEC to work through its institutes and produces number of graduates, M. Phil and PhDs and progressing towards more. According to education report in economic survey of Pakistan (2010-11) "Since 2002, HEC has sent about 4,313 scholars in the technically advanced countries for research degrees such as M. Phil and $\mathrm{PhD}$ out of these 1,214 have completed and returned to the country" and "more than $750 \mathrm{PhD}$ degrees were awarded by Pakistani universities in 2010 alone."

Higher education has never gain so much importance in the last decade that it has never seen before. The government spending in terms of enhancing the knowledge base industry enhances funding for universities and improves the quality of education and life. Following table shows the financial allocation to universities during the period between 1995 and 2009 divided into pre HEC and HEC eras. 
Table: 4 Government Spending on Higher Education in Pakistan during 1995 - 2009

\begin{tabular}{|c|c|c|c|}
\hline & Year & $\begin{array}{c}\text { (Development \& Non Development } \\
\text { Funds) } \\
\text { (Billion, PKR.) }\end{array}$ & $\begin{array}{c}\text { Annual Increase } \\
\text { In terms of percentage }\end{array}$ \\
\hline \multirow{6}{*}{ 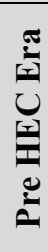 } & 1995-1996 & 1.9 & - \\
\hline & 1996-1997 & 2.1 & 9.7 \\
\hline & 1997-1998 & 2.3 & 10.3 \\
\hline & 1998-1999 & 2.2 & (4.3) \\
\hline & $1999-2000$ & 2.5 & 11.5 \\
\hline & $2000-2001$ & 3.0 & 22.0 \\
\hline & & & \\
\hline \multirow{8}{*}{ 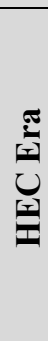 } & $2001-2002$ & 3.8 & - \\
\hline & $2002-2003$ & 8.4 & 120.3 \\
\hline & 2003-2004 & 10.3 & 22.8 \\
\hline & 2004-2005 & 14.3 & 39.3 \\
\hline & $2005-2006$ & 19.5 & 35.8 \\
\hline & $2006-2007$ & 28.6 & 47.2 \\
\hline & $2007-2008$ & 33.8 & 18.0 \\
\hline & $2008-2009$ & 33.8 & 0.0 \\
\hline
\end{tabular}

Source: Ahson, U., \& Aftab, K. (2009, December) Finanicial Sustainability of Higher Education in Pakistan: A Public Sector University's Perspective. SAARC Journal of Human Resource Development, 5(1),71.

Financing of universities in pre HEC era was not appreciable due to which the process of human development was not progressing as the table below exhibits the numbers of students were gradually increased in HEC era and that was around 868,641 in 2009-10. According to Pakistan's higher education policy note although the budget which has been allocated in HEC era is very huge yet it came after prolong underfunding. (Khalid \& Ahson, 2009, p.72) Thus that huge amount of finance in this decade (2001-2010) has been used in the recovery of the performance of past decade's underfunding. However the future of HEC is also under threat after the eighteenth amendment in the constitution of Pakistan, which ask higher education to be treated as a provincial subject and each province has to look at its resources and priorities.

In contrast to higher education, the growth of basic education that is primary and secondary at school levels in Pakistan has been stagnant for many years. Irony of the fact is that the economy has not been able to decide the fundamental parameters of basic education. Time and again, questions about medium of instruction or the academic calendar are being raised reflecting that the concerned policy makers have not yet decided what they have to do and how they have to do. Various education policies have been given over the time which has resulted in running parallel schooling systems thereby adding confusion to the students and parents. In Pakistan, one can find government schools, private schools, madarsah (religious schools), private boards, local boards, federal boards and Cambridge ( $\mathrm{O}$ and $\mathrm{A}$ levels) system all of which has created so many divergences and divisions within the society and paved way for social rift and regional disparities too.

Furthermore situations in the government run schools have been seriously dismal as the infrastructural facilities are highly underdeveloped which could be considered as a significant hindrance to the growth of basic education in the country. Although the government has been allocating current expenditure every year for the maintenance purposes yet there existed so much to be done as if nobody has thought about these schools. According to economic survey (2009-2010) 9.8\% schools were without a building, 32.7\% without boundary wall, $33.6 \%$ without drinking water, $35.4 \%$ without latrine and 59.0 without electricity. This situation represent that it's not only about public expenditure but also about the feedback and accountability of those expenditures as well.

The current situation in Pakistan requires a lot more in the field of education to become socially, economically and politically viable nation. Education has the potential to uplift any society but for it to happen there is a strong need to transform the education policy and make it equal and available for all.

\section{Conclusion}

The rational allocation and utilization of public expenditure would result into an economic development of the country. The allocation and utilization of public expenditure in Pakistan have been very little towards development. The debt servicing and defense expenditure have increased by a greater percentage every year. The huge amount that had been borrowed in the past, had they been utilized in the development projects such as education; the results would have been a developed and rich economy. Budget allocation and expenditure has to follow simple rule that it should aim towards generating more resources for the economy 
rather than eating out the existing resources. However in case of Pakistan there are certain indispensible factors that posses serious political challenges and not letting it do, what it should be doing. The public expenditures should however be directed towards infrastructure primarily education so that it would be available to every individual with no ethnic, gender and geographical discrimination so that economic development is encouraged.

\section{References and Bibliography}

[1]. Abbas, F., Mushtaq, K. (December 25, 2006). Defense spending and Economic Development, Daily Dawn.

[2]. Ahson, U., \& Aftab, K. Finanicial Sustainability of Higher Education in Pakistan: A Public Sector University's Perspective. SAARC Journal of Human Resource Development, 5(1), 2009 67-87.

[3]. Bhatia, H. Public Finance (New Delhi: Vikas Publishing House 1996)

[4]. Development Education program, "Economic Development", World Bank Group.

[5]. Dewett, K. K. Modern Economic Theory (New Delhi, India: Shyam Lal Charitable Trust 2005)

[6]. Farooq, O. "Education", Economic survey of Pakistan 2009-10

[7]. Federal Budget 2009-12, Ministry of Finance Pakistan.

[8]. Herrick B., \& Kindleberger, C. P. Economic Development (Singapore: mcgraw-Hill 1983)

[9]. Huda, S. The Economic Development of Pakistan (Karachi: Royal book Company 1996)

[10]. M., H. B. Razi, S. Social Welfare Measurement in Pakistan. Pakistan Economic and Social review, 45 (1), 2007 55-58.

[11]. Saeed K.A. Economy of Pakistan ( $3^{\text {rd }}$ ed.). (Lahore: S.A. Salam publications 1995)

[12]. Sherani, S. \& Gul, N. "Public Finance" Economic survey of Pakistan (2009-2010)

[13]. Todaro, M. P. Economic Development (seventh ed.). (New York: Addision Wesley Longman Inc 2000)

[14]. Aftab, Khalid. "Financing Higher Education in Pakistan in the 21St Century: New Challenges and Constraints". Conference Paper presented in Financing Higher Education in Pakistan held at GC University, Lahore Pakistan 2008.

[15]. Igbal, Aleem. Problems and Prospects of Higher Education in Pakistan. Phd Thesis, University of Arid Agriculture, Rawalpindi, Pakistan. 2004

[16]. Isani, Usman Ali. Higher Education in Pakistan. Phd Thesis, National University of Modern Languages, Islamabad, Pakistan. 2001

[17]. Higher Education Commission. Medium Term Development Framework 2005-10. Planning Commission, Government of Pakistan, Islamabad. 2005

[18]. State Bank of Pakistan. Annual Report 2009.

[19]. Tapir, Pervez and Nadia Saleem. 2008. "Financing Higher Education in Pakistan: Issues of Fiscal Sustainability".

[20]. Hogendorn, J.S. Economic Development (New York: Harper-Row, 1987)

[21]. Herrick, B. And Kindleberger, C.P. Economic Development (mcgraw-Hill, Singapore 1983)

[22]. Afxentiou, P., \& Serletis, A. Foreign Indebtedness in Low and Middle Income Developing Countries. Social and Economic Studies, 1996 133-159.

[23]. Alesina, A., \& Ardagna, S. Tale of Fiscal Adjustment. Economic Policy, 1998 488-545.

[24]. Arnone, M., \& Presbitero, A. F. External debt sustainability and domestic debt in Heavily Indebted Poor Countries. MPRA Paper, Paper No. 1396. 2006

[25]. Barro, R. J., \& Sala-I-Martin, X. Public Finance in Models of Economic Growth. The Review of Economic Studies, 59 (4), 1992 645-661.

[26]. Battaglini, M., \& Coate, S. A Dynamic Theory of Public Spending, Taxation and Debt. American Economic Review, 98 (1), 2008

[27]. Bleaney, M., Gemmell, N., \& Kneller, R. Testing the Endogenous Growth Model: Public Expenditure, Taxation, and Growth over the Long Run. The Canadian Journal of Economics, 34 (1), 2001 36-57.

[28]. Chaudhary, M. A., \& Anwar, S. Foreign Debt, Dependency, and Economic Growth in South Asia. The Pakistan Development Review, 39 (4), 2000 551-570.

[29]. Cunningham, R. The Effects of Debt Burden on Economic Growth in Heavily Indebted Nations. Journal of Economic Development, $1993115-126$

[30]. Mavrov, H. The Size of Government Expenditure and the Rate of Economic Growth in Bulgaria. Economic Alternatives (1), 2007 pp. 52-63.

[31]. Ministry of Finance. Economic Survey 2006-07. Government of Pakistan, Finance Division Economic Afairs Wing, Islamabad.

[32]. Ministry of Finance. Economic Survey 2007-08. Government of Pakistan, Finance Division Economic Affairs Wing, Islamabad.

[33]. Ministry of Finance. Economic Survey 2008-09. Government of Pakistan, Finance Division Economic Affairs Wing, Islamabad.

[34]. Ministry of Finance. Economic Survey 2009-10. Government of Pakistan, Finance Division Economic Affairs Wing, Islamabad.

[35]. Ministry of Finance. Economic Survey 2010-11. Government of Pakistan, Finance Division Economic Affairs Wing, Islamabad.

[36]. Siddiqui, R. The Pakistani Economy: Performance and Challenges. The Muslim World, 96, 2006 251-268. 